\title{
Lack of Hormone Binding in COS-7 Cells Expressing a Mutated Growth Hormone Receptor Found in Laron Dwarfism
}

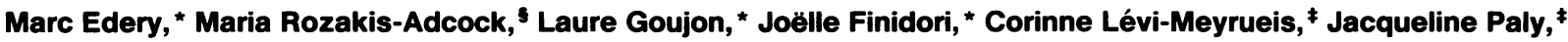 \\ Jean Djiane, " Marie-Catherine Postel-Vinay, * and Paul A. Kelly* \\ *Institut National de la Santé et de la Recherche Médicale, Unité 344, Endocrinologie Moléculaire, Faculté Necker-Enfants Malades, \\ 75015 Paris; ${ }^{\ddagger}$ Institut National de la Recherche Agronomique, Unité d'Endocrinologie Moléculaire, Bâtiment des Biotechnologies, 78352 \\ Jouy-en-Josas Cedex, France; and ${ }^{\S}$ Laboratory of Molecular Endocrinology, \\ McGill University, Royal Victoria Hospital, Montreal, Canada H3A $1 \mathrm{Al}$
}

\begin{abstract}
A single point mutation in the growth hormone $(\mathrm{GH})$ receptor gene generating a Phe $\rightarrow$ Ser substitution in the extracellular binding domain of the receptor has been identified in one family with Laron type dwarfism. The mutation was introduced by site-directed mutagenesis into cDNAs encoding the full-length rabbit GH receptor and the extracellular domain or binding protein (BP) of the human and rabbit $\mathrm{GH}$ receptor, and also in cDNAs encoding the full length and the extracellular domain of the related rabbit prolactin (PRL) receptor. All constructs were transiently expressed in COS-7 cells. Both wild type and mutant full-length rabbit GH and PRL receptors, as well as GH and prolactin BPs (wild type and mutant), were detected by Western blot in cell membranes and concentrated culture media, respectively. Immunofluorescence studies showed that wild type and mutant full-length GH receptors had the same cell surface and intracellular distribution and were expressed with comparable intensities. In contrast, all mutant forms (fulllength receptors or BPs), completely lost their ability to bind ligand. These results clearly demonstrate that this point mutation (patients with Laron syndrome) does not modify the synthesis or the intracellular pathway of receptor proteins, but rather abolishes ability of the receptor or BP to bind $\mathrm{GH}$ and is thus responsible for the extreme $\mathrm{GH}$ resistance in these patients. ( J. Clin. Invest. 1993. 91:838-844.) Key words: gene • point mutation - mutagenesis - growth hormone • prolactin • receptor $\bullet$ binding protein
\end{abstract}

\section{Introduction}

Laron type dwarfism (LTD) ${ }^{1}$ is a genetic disease caused by extreme resistance to growth hormone $(\mathrm{GH})$ action $(1,2)$. Several abnormalities in the $\mathrm{GH}$ receptor gene have recently

Address correspondence to Dr. Paul A. Kelly, INSERM, Unité 344, Faculté de Médecine Necker-Enfants Malades, 156 rue de Vaugirard, 75730 Paris Cedex 15, France.

Received for publication 13 December 1991 and in revised form 22 September 1992.

1. Abbreviations used in this paper: $\mathrm{BP}$, binding protein; $\mathrm{GH}$, growth hormone; GHBP, GH binding protein; GHR, GH receptor; $h \mathrm{GH}$, human growth hormone; LTD, Laron type dwarfism; oPRL, ovine prolactin; PRL, prolactin; PRLR, PRL receptor; PRLBP, PRL binding protein; rb, rabbit; RER, rough endoplasmic reticulum.

J. Clin. Invest.

(c) The American Society for Clinical Investigation, Inc. 0021-9738/93/03/0838/07 \$2.00

Volume 91, March 1993, 838-844 been shown in families with LTD (3-5). In a Tunisian family with four children presenting LTD, a point mutation in the $\mathrm{GH}$ receptor gene has been identified that generates a Ser in place of a Phe at position 96 in the extracellular domain of the receptor (4). It was suggested that this mutation results in a functionally inactive $\mathrm{GH}$ receptor in these patients. However, Bass et al. (6) reported that the mutated GH binding protein (GHBP) expressed in Escherichia coli has binding characteristics identical to those of the wild type BP. Recently, Duquesnoy et al. (7) reported that the Phe to Ser mutation of the human $\mathrm{GH}$ receptor expressed in COS-7 cells did not affect binding but rather altered intracellular trafficking of the receptor.

We have expressed the wild type and mutant full-length rabbit GH receptor and the wild type and mutant rabbit and human BPs in COS-7 cells. Our study was extended to include the prolactin receptor that belongs to the $\mathrm{GH} /$ prolactin (PRL) receptor family and in which this phenylalanine is conserved (8). The expression of the receptors was assessed by Western blot and immunofluorescence studies. The binding activity of the expressed receptors was assayed in the transfected cell membranes and medium.

\section{Methods}

\section{Materials}

The following products were obtained from the cited sources: recombinant human GH (hGH), Serono Laboratories (Boulogne, France); ovine PRL (oPRL), NIDDK-16, National Hormone and Pituitary Program ( Baltimore, MD); MEM, Ham's F12, transferrin, insulin, glutamine, nonessential amino acids, penicillin, and streptomycin, Flow Laboratories, (Paris, France); carrier-free $\mathrm{Na}\left[{ }^{125} \mathrm{I}\right]$, Amersham International (Bucks, UK); protein PAK 300 SW, Waters Associates (Milford, MA); acrylamide agarose column, (ACA 54; LKB, Bromma, Sweden ); Immobilon-P and CX-10 cartridges, Millipore Corp. (Bedford, MA); X-Omat AR5 film, Eastman Kodak, (Rochester, NY). Antibody against the $\mathrm{GH}$ receptor $(\mathrm{GHR})$ ( $\mathrm{mAb} 5$ ) was obtained from Agen, Inc (Parsippany, NJ). Polyclonal antibody against endoplasmic reticulum was a generous gift from D. Louvard, Institut Pasteur (Paris, France). Plasmids containing rabbit and human GHR (pBR.hGHR and pBS.rbGHR, respectively) are generous gifts from Dr. William Wood, Genentech (South San Francisco, CA).

\section{Iodination}

$\left[{ }^{125} \mathrm{I}\right] \mathrm{hGH}$ was prepared using chloramine-T. Its specific activity ranged from 80 to $140 \mu \mathrm{Ci} / \mu \mathrm{g}$. [ $\left.{ }^{125} \mathrm{I}\right] \mathrm{oPRL}$ was prepared using chloramine- $T$ and purified on an acrylamide agarose column, with a specific activity ranging from 76 to $80 \mu \mathrm{Ci} / \mu \mathrm{g}$. $\left[{ }^{125} \mathrm{I}\right] \mathrm{mAb} 5$ was prepared using chloramine-T and purified on a G-75 Sephadex column with a specific activity ranging from 7 to $15 \mu \mathrm{Ci} / \mu \mathrm{g}$.

\section{Site-directed mutagenesis}

GHR mutants were constructed using site-directed mutagenesis, according to the method of Kunkel (9). Briefly, cDNAs of the full-length 
rbGHR (pBS.rbGHR) and a portion of the hGHR (1,057-bp EcoRI fragment from pBR.hGHR) (10) were subcloned into the vector M13mp18 and subsequently used to generate single-stranded template in RZ1032 cells. Phe to Ser mutations were introduced using synthetic oligonucleotides, 25 nucleotides in length, containing a TTT $\rightarrow$ TCT/ $\mathrm{C}$ mutation in the center of the primer. The soluble secreted forms of both GH receptors were constructed using a 27-nucleotide oligomer designed to introduce a stop codon at amino acid 246, one amino acid before the transmembrane domain. The PRL receptor 2 ( PRLR $\left._{2} 2\right)$ cDNA (8) encoding the extracellular and transmembrane domains of the rabbit PRL receptor was inserted into M13mp19 vector. Sitedirected mutagenesis with synthetic oligonucleotide, 20 nucleotides in length, containing a TTT $\rightarrow$ TCT/C mutation in the center of the oligonucleotide was performed to introduce a Phe to Ser mutation at position 64 . The 1,600 -bp fragment of $\operatorname{PRLR}_{2} 2$ (8) was inserted into pECE expression vector and full-length cDNA was constructed as previously described (8). The extracellular domain of PRLR was constructed by digesting pECE PRLR 2 at the SacI sites found after the glutamic acid codon that precedes the transmembrane domain and in the polylinker of pECE. The resulting 370-bp SacI-SacI fragment was separated by gel electrophoresis and the expression plasmid containing coding region of extracellular domain of PRLR was ligated with $T_{4}$ DNA ligase. Stop codons are present $-3^{\prime}$ to the polylinker of pECE in all three reading frames, before the SV40 polyadenylation signal and poly (A) tract, which accommodate any 3 ' truncation of the cDNA.

\section{Cell line}

COS-7 monkey kidney cells were grown as monolayers in serum-free medium that is a 1:1 mixture of MEM and Ham's F12 supplemented with transferrin $(10 \mu \mathrm{g} / \mathrm{ml})$, insulin $(80 \mathrm{mU} / \mathrm{ml})$, glutamine $(2.5$ $\mathrm{mM}$ ), nonessential amino acids, penicillin, and streptomycin ( $100 \mathrm{U} /$ $\mathrm{ml})$ at $37^{\circ} \mathrm{C}$ in a $5 \% \mathrm{CO}_{2}$ atmosphere.

\section{Membrane fraction preparations}

Cells were scraped off in $1 \mathrm{ml}$ PBS and centrifuged for $5 \mathrm{~min}$ at $2,000 \mathrm{~g}$. After resuspension of the pellet in $0.5 \mathrm{ml} 25 \mathrm{mM}$ Tris- $\mathrm{HCl}, \mathrm{pH} 7.4,10$ $\mathrm{mM} \mathrm{MgCl}$ (Tris-Mg buffer), cells were lysed by three freeze-thaw cycles and centrifuged at $17,600 \mathrm{~g}$ for $10 \mathrm{~min}$ at $4^{\circ} \mathrm{C}$. The pellet, referred to as the total particulate fraction, was resuspended in Tris-Mg buffer. Microsomal fractions were prepared by differential centrifugation: after a first centrifugation for $15 \mathrm{~min}$ at $2,000 \mathrm{~g}$, the supernatant was centrifuged at $100,000 \mathrm{~g}$ for $30 \mathrm{~min}$. The pellet was resuspended in Tris-Mg buffer. Membrane fractions were stored in liquid nitrogen until binding measurements. Protein concentrations were determined by the method of Lowry, using BSA as a standard.

\section{Transfection assays}

COS-7 cells were plated on 100-mm culture dishes and grown to $50 \%$ confluency. Cells were transfected either with the wild type or the Phe $\rightarrow$ Ser mutant by the calcium phosphate precipitation procedure using 10- $\mu \mathrm{g}$ expression plasmid. Cells were harvested $72 \mathrm{~h}$ after transfection and the culture medium was collected and concentrated 10 -fold with CX-10 immersible cartridges.

\section{Western blots}

$G H R$ and $G H$ binding protein $(G H B P) .100 \mu \mathrm{g}$ membrane protein of total particulate fraction or $10 \mu \mathrm{l}$ of concentrated cell culture medium per lane were separated in a $7.5 \%$ polyacrylamide SDS gel according to Laemmli (11) and were transferred onto Immobilon-P. The membrane was soaked in $1 \%(\mathrm{wt} / \mathrm{vol}$ ) ethanolamine $\mathrm{pH} 7.0$ containing $2 \%$ milk ( wt / vol) for $2 \mathrm{~h}$ at $23^{\circ} \mathrm{C}$, then in PBS, $\mathrm{pH} \mathrm{7.4,} \mathrm{for} 30 \mathrm{~min}$. Nonspecific signals were reduced by preincubating $\left[{ }^{125} \mathrm{I}\right] \mathrm{mAb} 5\left(10^{6} \mathrm{cpm}\right)$ diluted in $2 \mathrm{ml}$ PBS 1\% BSA with Western blots of soluble or membrane protein from nontransfected COS-7 cells. Then incubations with $\left[{ }^{125} \mathrm{I}\right] \mathrm{mAb} 5$ were done at $23^{\circ} \mathrm{C}$ for $24 \mathrm{~h}$. Finally, blots were washed four times for $10 \mathrm{~min}$ at $23^{\circ} \mathrm{C}$ in PBS, pH 7.4, 0.05\% Triton X-100, dryed on filter paper, and exposed 2-3 d using X-OMAT AR 5 film with an intensifying screen.

$P R L R$ and PRL binding protein (PRLBP). $100 \mu \mathrm{g}$ membrane protein of total particulate fraction or $10 \mu \mathrm{l}$ of concentrated cell culture medium per lane were separated in a $7.5 \%$ polyacrylamide SDS gel and were transferred onto nitrocellulose membrane. The membrane was saturated overnight in $10 \mathrm{mM} \mathrm{Na} \mathrm{H}_{2} \mathrm{PO}_{4}, 150 \mathrm{mM} \mathrm{NaCl}, 0.05 \%$ Tween 20 with $5 \%$ milk, and incubated with a goat anti-rbPRLR antiserum (polyclonal 46) diluted 1:100 in the same buffer. The bands were revealed with an anti-goat antibody conjugated to alkaline phosphatase.

\section{Immunofluorescence studies}

For immunofluorescence studies, cells were grown on glass slides. Culture and transfection conditions were the same as described above. After $72 \mathrm{~h}$, cells were fixed with $3 \%$ paraformaldehyde and treated or not with $0.2 \%$ Triton X-100. Indirect immunofluorescence was performed as described (12); the $\mathrm{GH}$ receptor was identified with mAb5 ( $5 \mu \mathrm{g} / \mathrm{ml}$ ) followed by incubation with a fluoresceine-conjugated mouse IgG-specific antibody (Biosys, Compiègne, France). To check that the staining obtained in the absence of Triton was caused by cell surface labeling of the GH receptors, a polyclonal anti-endoplasmic reticulum antibody (13) was added to mAb5 and visualized with a rhodamine-conjugated rabbit anti-IgG antibody (Biosys). The absence of rhodamine signal when the cells were not preincubated with Triton excluded an artefactual permeabilization by paraformaldehyde.

\section{Binding assays}

GHBP. Concentrated culture medium $(10 \times)$ from transfected COS-7 cells $(10-20 \mu \mathrm{l})$ was incubated for $20 \mathrm{~h}$ at $4^{\circ} \mathrm{C}$ with $\left[{ }^{125} \mathrm{I}\right] \mathrm{hGH}\left(2 \times 10^{5}\right.$ cpm) in $200 \mu \mathrm{l} 0.1 \mathrm{M}$ potassium phosphate, $\mathrm{pH} 7.0$, with $0.1 \%$ BSA. A parallel incubation was carried out in the presence of excess of unlabeled hGH $(5 \mu \mathrm{g})$ to evaluate nonspecific binding. After filtration through a $0.45-\mathrm{mm}$ minifilter (Millipore Corp.), the entire incubation mixture was injected onto a HPLC Protein Pak 300SW column as described previously (14). Elution was performed isocratically using a degassed buffer ( $100 \mathrm{mM} \mathrm{Na}_{2} \mathrm{SO}_{4}$ and $100 \mathrm{mM}$ potassium phosphate, $\mathrm{pH} 7.0$ ) pumped at a rate of $0.5 \mathrm{ml} / \mathrm{min}$. Binding of $\mathrm{GH}$ is expressed as the radioactivity in the individual peak divided by the total radioactivity in the peaks.

Immunoprecipitation of PRLBP. To analyze prolactin binding by immunoprecipitation, culture medium $(50 \mu \mathrm{l})$ was incubated with [ $\left.{ }^{125} \mathrm{I}\right]$ oPRL $\left(5 \times 10^{4} \mathrm{cpm}\right)$ in the absence or presence of increasing concentrations of unlabeled oPRL in a total volume of $500 \mu$ l of Tris buffer ( $25 \mathrm{mM}$ Tris- $\mathrm{HCl}, \mathrm{pH} 7.5,10 \mathrm{mM} \mathrm{MgCl} 2,0.1 \%$ BSA). After 16 $\mathrm{h}$ at room temperature, polyclonal antibodies ( $10 \mu \mathrm{l}$ of goat serum 46 ) to the prolactin receptor were added and the incubation was continued for two additional hours. $500 \mu \mathrm{l} \gamma$ globulin $(0.1 \%)$ and $1 \mathrm{ml}$ polyethylene glycol (final concentration $12.5 \%$ ) in phosphate buffer was added. The tubes were centrifuged, the supernatant was discarded, and the radioactivity of the pellet was recorded by a $\gamma$ counter (LKB).

\section{Measurement of membrane receptors}

$G H R$. Competition experiments and Scatchard analyses were performed by incubating $50 \mu \mathrm{g}$ of membrane protein in $0.5 \mathrm{ml} 25 \mathrm{mM}$ Tris- $\mathrm{HCl} \mathrm{pH} \mathrm{7.5,} 10 \mathrm{mM} \mathrm{MgCl}_{2}, 0.1 \% \mathrm{BSA}$, with $30,000 \mathrm{cpm}$ of [ $\left.{ }^{125} \mathrm{I}\right]-$ hGH and increasing concentrations $(0.25 \mathrm{ng}$ to $1 \mu \mathrm{g})$ of unlabeled hGH. After $20 \mathrm{~h}$ at $23^{\circ} \mathrm{C}$, bound and free hormones were separated by centrifugation or filtration and the pellets were counted in a $\gamma$ counter.

$P R L R$. Competition experiments and Scatchard analyses were performed by incubating $25 \mu \mathrm{g}$ of membrane protein in $0.5 \mathrm{ml}$ of assay buffer $(25 \mathrm{mM}$ Tris $\mathrm{HCl}$, pH $7.5,10 \mathrm{mM} \mathrm{MgCl}, 0.1 \%$ BSA, $0.02 \%$ sodium azide) with $50,000 \mathrm{cpm}$ of [ $\left.{ }^{125} \mathrm{I}\right] \mathrm{oPRL}$ and increasing concentrations $(0.25 \mathrm{ng}-1 \mu \mathrm{g})$ of unlabeled oPRL. After $20 \mathrm{~h}$ at $23^{\circ} \mathrm{C}$, incubations were diluted with $3 \mathrm{ml}$ buffer, and centrifuged, and the pellets were counted in a $\gamma$ counter.

Scatchard plot analyses were performed using the program Ligand (15). 


\section{Results}

\section{Expression of the $G H$ receptor $/ B P$}

The full-length rabbit GH receptor and BP were expressed in COS-7 cell membranes and culture medium, respectively. Fig. $1 a$ shows Western blot analysis using a monoclonal antibody (mAb5) specific to the GH receptor. The expression in COS-7 cell membranes (lanes 2 and 3 ) is comparable for the wild type and the mutated rabbit $\mathrm{GH}$ receptor, which migrate with relative molecular masses of 120,000 and 230,000 .

In the concentrated media of transfected COS- 7 cells, both the wild type and the mutant forms of the human and rabbit
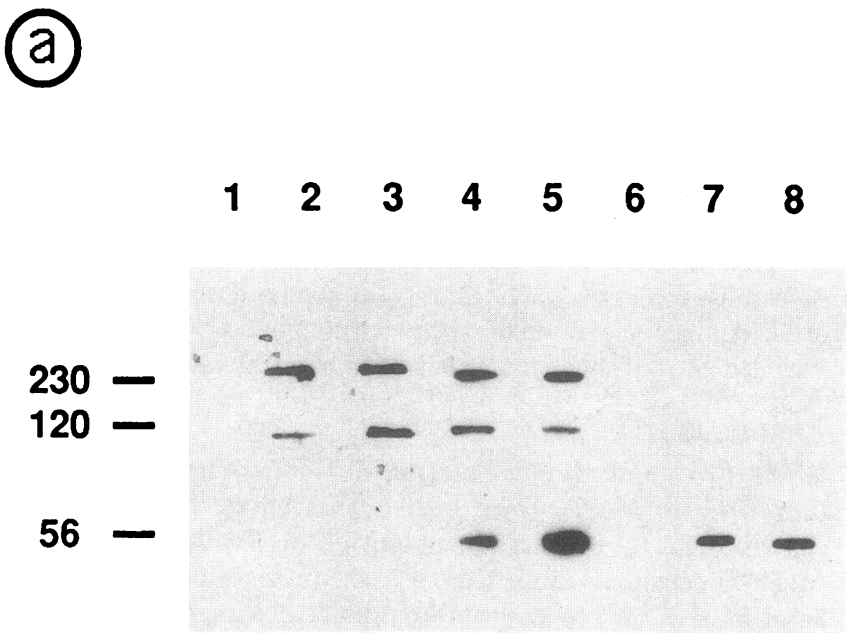

(b)

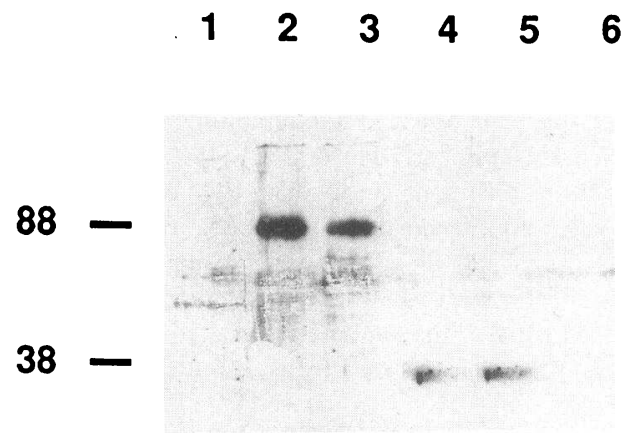

Figure 1. Western blot analysis of GH and PRL receptors and BPs. (a) Western blots of membrane fractions (lanes 2 and 3 ) or culture media (lanes 4, 5, 7, and 8 ) of COS-7 cells transfected with expression plasmids containing: wild type rbGHR (lane 2), mutated rbGHR (lane 3 ), wild type rbGHBP (lane 4), mutated rbGHBP (lane 5), wild type hGHBP (lane 7), and mutated hGHBP (lane 8 ). Lane 1 contains membrane fraction and lane 6 contains culture medium from COS-7 cells that had not been transfected. $(b)$ Western blots of membrane fractions (lanes 2 and 3 ) or culture media (lanes 4 and 5) of COS-7 cells transfected with expression plasmids containing: wild type rbPRLR (lane 2), mutated rbPRLR (lane 3), wild type rbPRLBP (lane 4), and mutated rbPRLBP (lane 5). Lane 1 contains membrane fraction and lane 6 contains culture medium of COS-7 cells that had not been transfected. Numbers on the left indicate the $M_{\mathrm{r}}\left(\times 10^{-3}\right)$ of the bands.
BPs are detected. The wild type and the mutant human BP migrate with the expected molecular mass of 56,000 (lanes 7 and 8 ). In addition to the $56,000 M_{\mathrm{r}}$ band, two other bands, for both wild type and the mutant forms of rabbit BP (lanes 4 and 5 ) are evident, suggesting the presence of dimers and oligomers.

\section{Expression of the prolactin receptor $/ B P$}

In membranes of COS-7 cells transfected with the cDNA of the prolactin receptor and analyzed by immunoblot, a single band of $88 \mathrm{kD}$ is detected for both the wild type and the mutated receptor (Fig. $1 b$, lanes 2 and 3 ). In concentrated media, the prolactin BPs are expressed; they are detected on the immunoblot as a 38,000 $M_{\mathrm{r}}$ band (lanes 4 and 5 ).

In the membranes and culture media of COS-7 cells which had not been transfected, no protein appears on the immunoblots, as can be seen in lanes 1 and 6 of Figs. $1 a$ and $b$.

\section{Immunofluorescence studies}

Transfected COS-7 cells were examined by double fluorescence using monoclonal antibody 5 against the GH receptor (Fig. 2). Left panels correspond to cells transfected with the wild type rabbit GH receptor and right panels, to cells transfected with the mutated form of the receptor. In nonpermeabilized cells, labeling was faint and diffuse over the entire surface of positive cells. However, the cell borders were clearly seen and no significant background was observed in neighboring negative cells. No significant difference could be detected between cells expressing wild type $(A)$ or mutant receptors $(B)$. In permeabilized cells, the pattern of fluorescence was completely different. The receptors appeared concentrated in the perinuclear area at one side of the nucleus, suggesting a localization in the Golgi complex. A fine reticular network that spread throughout the cell cytoplasm was also observed; this pattern was in favor of a labeling of the endoplasmic reticulum compartment. However, similar distribution of the fluorescence was observed in either wild type or mutant transfected cells and again no significant difference in the intensity of the signal could be detected. Double labeling with anti-rough endoplasmic reticulum (RER) antibody was performed as a control to better localize cell surface versus intracellular signals. No labeling was detected when cells were not treated with Triton X-100 (data not shown). In permeabilized cells, we observed that the distribution of the fluorescence with mAb5 $(C$ and $D)$ and with the anti-RER antibody ( $E$ and $F$ ) partially colocalized in positive cells. Similar results were obtained in four independent experiments.

\section{Binding studies}

GHBPs. The binding activity of the soluble GHBPs was assessed using gel filtration and HPLC. The elution profiles of $\left[{ }^{125} \mathrm{I}\right] \mathrm{hGH}$ incubated with the different culture media are shown in Fig. 3. The hGHBP complexes are eluted at the expected time, for the wild type human and rabbit BPs ( $a$ and $c)$. In the concentrated culture media where the mutated human and rabbit BPs are expressed, no $\mathrm{GH}$ binding activity is found as shown in Figs. 3, $b$ and $d$. Affinity constants, calculated by Scatchard analyses, are shown in Table I. They are comparable to the binding affinities previously found for the human plasma and the rabbit plasma GHBP $(14,16)$.

GHR. [ $\left.{ }^{125} \mathrm{I}\right] \mathrm{hGH}$ specifically binds to membrane fractions prepared from COS-7 cells that were transfected with the cDNA of the full-length rbGHR (Table II); the expected high 

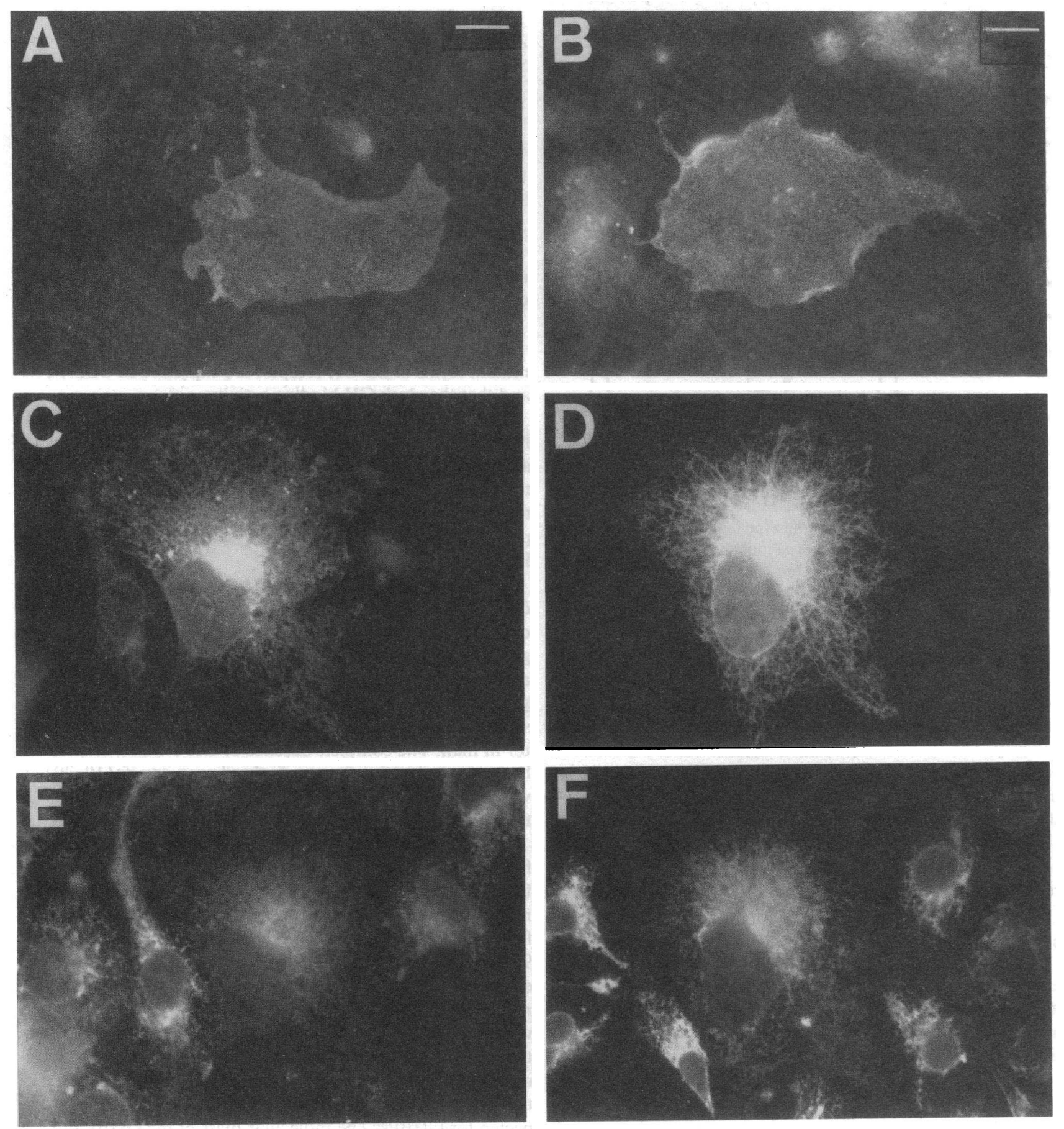

Figure 2. Immunocytochemical localization of wild type and mutant rabbit GH receptors. COS-7 cells were transfected with expression plasmids containing wild type rb GHR (left panels) or mutated rb GHR (right panels). ( $A$ and $B$ ) Paraformaldehyde fixed cells labeled with mAb5 and visualized with a fluoresceine-coupled second antibody. $(C-F)$ Paraformaldehyde fixed and detergent permeabilized cells before incubation with both mAb5 and RER polyclonal antibody. Labeling with mAb5 was visualized with a fluoresceine-coupled second antibody $(C$ and $D)$; labeling of the same cells and of the surrounding transfected cells with the RER antibody was visualized with a rhodamine-coupled second antibody ( $E$ and $F$ ). Bars $=10 \mu \mathrm{m}$. This figure is of one experiment that is representative of four independent transfections carried out on separate days, and the visualization of $>500$ individual cells.

affinity is found (Table I). When the mutated full-length rbGHR is expressed in the cell membranes, no binding activity can be measured, either in total particulate fractions or in microsomes ( Table II). Binding studies have also been performed on whole cells in culture dishes; results confirmed the absence of GH binding in cells expressing the mutant receptor (not shown ).

$P R L R / B P$. Polyclonal antibodies against the rbPRLR were used to immunoprecipitate the [ ${ }^{125}$ I] oPRL-receptor complex for the binding assays. 

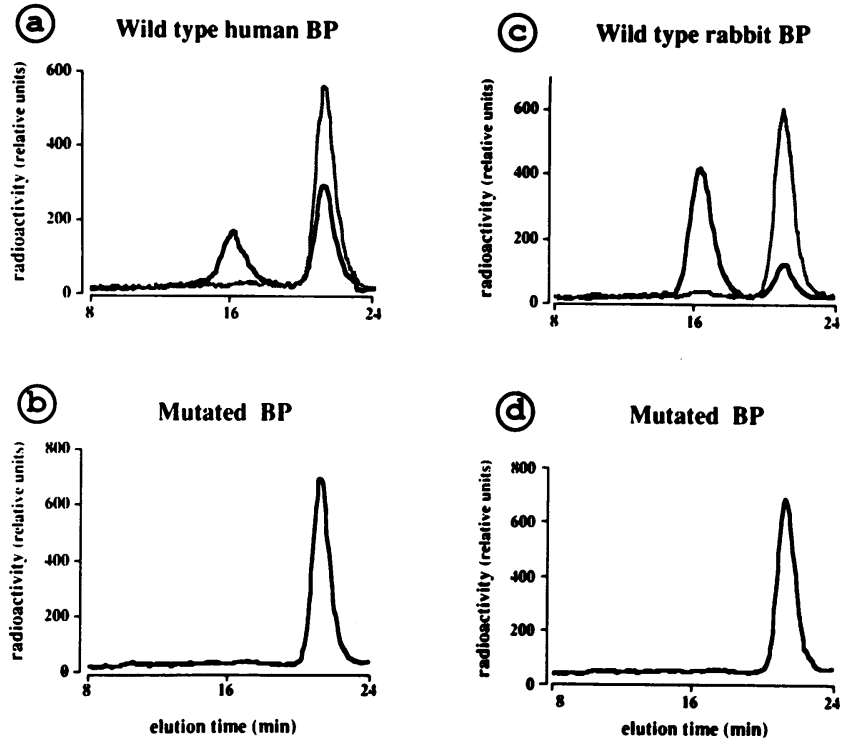

Figure 3. Binding assays of GHBPs. Elution profiles of [ $\left.{ }^{125} \mathrm{I}\right] \mathrm{hGH}$ incubated with the culture media obtained from cells transfected with expression plasmids containing ( $a$ ) wild type hGHBP; $(b)$ mutated hGHBP; $(c)$ wild type rbGHBP; and $(d)$ mutated rbGHBP. Incubations were performed in the absence (thick line) and presence of 5 $\mu \mathrm{g} \mathrm{hGH}$ (thin line) $(a$ and $c)$. The elution time of the BP- $\left[{ }^{125} \mathrm{I}\right] \mathrm{hGH}$ complex was $16 \mathrm{~min}$ and $43 \mathrm{~s}$. The elution time of free $\left[{ }^{125} \mathrm{I}\right] \mathrm{hGH}$ was $19 \mathrm{~min}$ and $42 \mathrm{~s}$.

As shown in Table I, the wild type full-length PRLR expressed in COS-7 cell membranes has the expected high binding affinity. The PRLBP expressed in the cell culture medium shows an affinity constant which is 11 times higher than that found for the PRLR and which is comparable to that previously reported for the PRLBP present in the rabbit milk (17). No binding activity was present either in cell membrane or in cell culture medium when the mutant forms of the PRLR/BP were expressed.

\section{Discussion}

After the demonstration in one family with LTD of a point mutation resulting in the substitution of a Phe by a Ser at position 96 in the extracellular domain of the $\mathrm{GH}$ receptor (4), two questions were raised: Is the mutated receptor expressed, and is this mutation the cause of the GH resistance in the patients? Our study provides a clear response: it demonstrates that the

Table I. Association Constant of GHR, GHBP, PRLR, and PRLBP Expressed in COS-7 Cells

\begin{tabular}{llllll}
\hline & \multicolumn{5}{c}{ Association constant } \\
\cline { 2 - 6 } & hGHBP & rbGHBP & rbGHR & rbPRLBP & rbPRLR \\
\hline & & & $n M^{-1}$ \\
Wild type & 0.5 & 3.6 & 3.0 & 38.5 & 3.3 \\
Serine mutant & 0 & 0 & 0 & 0 & 0 \\
& & & & & \\
\hline
\end{tabular}

Association constants have been calculated from Scatchard plots determined from competition experiments using total particulate fractions.
Table II. Specific Binding of $\left[{ }^{125} I\right]$ hGH to Membrane Fractions of COS-7 Cells Expressing the rbGHR

\begin{tabular}{lcc}
\hline & \multicolumn{2}{c}{$\left[{ }^{125}\right.$ I]hGH bound, \% of radioactivity } \\
\cline { 2 - 3 } & $\begin{array}{c}\text { Total particulate } \\
\text { fraction }\end{array}$ & $\begin{array}{c}\text { Microsomal membrane } \\
\text { fraction }\end{array}$ \\
\hline Wild type GHR & 15.9 & 24.6 \\
Serine mutant GHR & 0 & 0 \\
\hline
\end{tabular}

The specific binding is expressed as the percentage of total radioactivity per $100 \mu \mathrm{g}$ of membrane protein. Results of one representative experiment are presented.

mutant forms of the $\mathrm{GH}$ receptor are expressed in COS-7 cells and that they lack $\mathrm{GH}$ binding activity.

The GH receptor belongs to a new family of receptors that includes PRL and many cytokine receptors (18). The phenylalanine at position 96 in the extracellular domain of $\mathrm{GH}$ receptors is conserved in PRL receptors, where it is located at position 64 (8). Thus, our study was extended to the effect of this point mutation on the expression and binding activity of the PRL receptor.

The GH receptor cloned from rabbit and human liver (10) consists of a 620 -amino acid polypeptide chain containing an extracellular hormone-binding domain of 246 residues, a single transmembrane domain, and a cytoplasmic region of 350 amino acids. The extracellular domain is found in the serum as a GHBP. The evaluation of the GHBP in human plasma represents the only direct approach to the measurement of the receptor in man. The complete absence of $\mathrm{GH}$ binding activity has been reported in the plasma of other Laron dwarfs $(19,20)$, as well as in patients presenting this particular point mutation in their GH receptor gene (4).

We have not been able thus far to functionally express the full-length human GHR; for the present studies, cDNAs of the full-length rabbit GH receptor and of GHBPs for rabbit and man were used. In addition, the full-length and binding protein forms of the PRL receptor were also expressed. Replacing Phe 96 with Ser does not alter the expression of the protein. Western blot analyses reveal a protein of $120 \mathrm{kD}$ for the full-length rabbit GHR with the presence of a band of higher molecular weight, probably representing a dimer. The mutant form has the same molecular weight as the wild type receptor. The binding proteins, both wild type and mutant forms, are secreted in the culture media; their molecular mass $(56,000)$ is that expected for GHBPs: The molecular mass of the GHBP present in human plasma has been estimated, in crosslinking experiments, to be $55,000(21)$. Oligomerization is the probable explanation for the presence of higher molecular weight bands on Western blots of the rabbit GHBP. Several forms have been identified previously for mouse GHBP (22).

For the prolactin receptor also, substitution of this conserved Phe to Ser does not change the protein expression in COS-7 cells. The molecular masses of the full-length receptor and of the BP, 88,000 and 38,000 , respectively, are those expected for the two forms (23).

Whereas the mutation does not modify protein expression, it abolishes the hormone binding activity of the receptor proteins. Binding characteristics of the wild type receptors/BPs, as calculated from Scatchard plots, indicate a comparable affinity 
for the rabbit GHBP and membrane receptor. The affinity of the human GHBP is somewhat lower, but is identical to the affinity found for the human plasma BP (14). A very high binding affinity is found for the expressed PRLBP; it is much higher than the affinity of the membrane PRL receptor. Of interest is the comparison with the PRLBP that has been recently identified in rabbit milk, and which also shows an affinity for PRL, which is 10 times higher than that of the mammary cell membrane receptor (17).

A high level of GH binding activity was found in the microsomal fraction prepared from cells expressing the wild type $\mathrm{GH}$ receptor. However, no specific binding of $\left[{ }^{125} \mathrm{I}\right] \mathrm{hGH}$ could be detected in membrane fractions, on whole cells, or in culture media obtained from cells transfected with the mutant cDNAs. These results contradict those recently published by Duquesnoy et al. (7), who found GH binding activity in a lysosomal fraction prepared from COS-7 cells expressing the mutant $\mathrm{hGH}$ receptor. The distribution of the hGH receptor that was presented by these authors and that lead them to conclude that there was an abnormal processing of the mutant receptor is difficult to reconcile with respect to previous studies $(24,25)$. Their results showing the complete absence of wild type hGH receptors in a microsomal fraction make the interpretation of their binding studies difficult. Nevertheless, in cells expressing the mutant receptor, they did find some binding activity in a membrane subfraction that remains to be characterized. Thus, from the binding study presented by Duquesnoy et al. (7), it is difficult to draw definitive conclusions on the cell surface or intracellular localization of $\mathrm{GH}$ receptors.

On the other hand, we do not agree with the conclusion of Duquesnoy et al. (7), that the intracellular processing of the mutant receptor is abnormal. Our immunofluorescence studies have clearly shown in nonpermeabilized cells that the weak labeling observed with the anti-GH receptor antibody could be attributed to cell surface receptors. Although this labeling was diffuse, probably because of the inherent activity of the monoclonal antibody and the low number of cell surface receptors, it was clearly localized at the periphery of the cells. Under these conditions, intracellular antigens were not accessible to antireceptor antibody, as demonstrated by the absence of rhodamine (anti-RER) signal. Moreover, in Triton-treated cells, the images were strikingly different, with an intense signal of the antireceptor antibody in cells expressing both wild type and mutant receptors, probably related to the high concentration of $\mathrm{GH}$ receptors in intracellular membrane compartments. The signal was essentially perinuclear, probably corresponding to a localization in the endoplasmic reticulum and Golgi. Such a high proportion of $\mathrm{GH}$ receptors in intracellular organelles has already been demonstrated in other models, such as rat hepatocytes (24). One difference between the studies of Duquesnoy et al. (7) and the present results is that their study was performed on cells expressing the full-length human receptor, while our study used the full-length rabbit receptor. However, based on the observation of several independent COS-7 cell transfections, we conclude that there is no difference in either the intensity or the distribution of the signal between wild type and mutant receptors.

The phenylalanine residue at position 96 is located just after the first four cysteines, a region conserved among GH and PRL receptors, as well as cytokine receptors. This residue occurs at this particular position in the GH and PRL receptors of all species so far studied, suggesting that it could be part of the structural requirements that are crucial for proper ligand binding (26). However, the extracellular domain of the human GHR, in which Phe 96 had been substituted by a Ser, expressed in $E$. coli, showed normal GH binding characteristics $(6,27)$. The apparent discrepancy could reside in the choice of the expression model, since the hGHBP was expressed in bacterial cells by Bass et al. $(6,27)$, and in mammalian cells in our study. The absence of glycosylation did not alter $\mathrm{GH}$ binding to the wild type receptor, and normal binding was seen for the Phe $\rightarrow$ Ser mutant (6). On the other hand, we now demonstrate that in the mature glycosylated GHBP the phenylalanine residue is important for GH binding. These findings suggest that although the Phe residue may not be directly implicated in the ligand binding domain, it contributes to the conformational integrity of the mature protein. Glycosylation could result in changes in the tertiary folding of the receptor. In GHR, an $\mathrm{N}$-linked glycosylation site (Asn97) is located next to the conserved Phe. Finally, this mutation involves the replacement of a nonpolar residue (Phe) by a polar residue (Ser). In fact, the crystal structure of the hGHBP recently reported (28) shows that Phe 96 is the last residue of $\beta$-strand E, and that the phenylalanine side chain is indeed packed inside the $\beta$-sheet sandwich of the $\mathrm{NH}_{2}$-terminal domain. It thus seems reasonable to conclude that the Phe 96 to Ser mutation could have a disruptive effect on the structure of this domain, especially in view of the fact that the loop following this residue contains the most important hormone binding determinant, Trp 104 (de Vos, B., personal communication).

In summary, the phenylalanine to serine substitution found in one family of LTD is responsible for GH resistance in these patients. This substitution appears to alter ligand binding activity rather than normal processing of the receptor. The phenylalanine residue may be an important structural determinant for hormone binding to the mature $\mathrm{GH}$ receptor as well as the PRL receptor (26). The use of mammalian cells rather than bacterial cells to express GH and PRL receptors to study ligand binding represents a more realistic model for the interpretation of genetic defects of eukaryotes.

\section{Acknowledgments}

M. Edery and M. Rozakis-Adcock contributed equally to the work presented in this paper, and should be considered as co-first authors. The authors would like to thank G. Simonin, L. Bélair and Dr. L. Lesueur for their helpful collaboration, Dr. W. Wood for kindly providing the human and rabbit $\mathrm{GH}$ receptor $\mathrm{CDNAs}$, and $\mathrm{C}$. Coridun for expert secretarial assistance. We also greatly appreciate the information on the three-dimensional position of Phe 96 generously provided by Dr. A. M. de Vos.

This research was supported by grants from the Institut National de la Santé et de la Recherche Médicale, The Medical Research Council of Canada and the Institut National de la Recherche Agronomique.

\section{References}

1. Laron, Z., A. Pertzelan, and S. Mannhyeimer. 1966. Genetic pituitary dwarfism with high serum concentration of growth hormone: a new inborn error of metabolism? Isr. J. Med. Sci. 2:152-155.

2. Laron, Z., A. Pertzelan, M. Karp, A. Kowadlo-Silbergeld, and W. H. Daughaday. 1971. Administration of growth hormone to patients with familial dwarfism with high plasma immunoreactive growth hormone: measurement of sulfation factor, metabolic and linear growth response. J. Clin. Endocrinol. \& Metab. 33:332-342.

3. Godowski, P. J., D. W. Leung, J. R. Meacham, J. P. Galgani, R. Hellmiss, R. Keret, P. S. Rotwein, J. S. Parks, Z. Laron, and W. I. Wood. 1989. Character- 
ization of the human growth hormone receptor gene and demonstration of a partial gene deletion in two patients with Laron-type dwarfism. Proc. Natl. Acad. Sci. USA. 86:8083-8087.

4. Amselem, S., B. S. Duquesnoy, O. Attree, G. Novelli, S. Bousnina, M. C Postel-Vinay, and M. Goossens. 1989. Laron dwarfism and mutations of the growth hormone-receptor gene. N. Engl. J. Med. 231:989-995.

5. Amselem, S., M.-L. Sobrier, P. Duquesnoy, R. Rappaport, M. C. PostelVinay, M. Gourmelen, B. Dallapiccola, and M. Goossens. 1991. Recurrent nonsense mutations in the growth hormone receptor from patients with Laron dwarfism. J. Clin. Invest. 87:1098-1102.

6. Bass, S., S. H. Mulkerrin, and J. A. Wells. 1991. A systematic mutational analysis of hormone binding determinants in the human growth hormone receptor. Proc. Natl. Acad. Sci. USA. 88:4498-4502.

7. Duquesnoy, P., M. L. Sobrier, S. Amselem, and M. Goossens. 1991. Defective membrane expression of human growth hormone $(\mathrm{GH})$ receptor causes Laron-type GH insensitivity syndrome. Proc. Natl. Acad. Sci. USA. 88:1027210276.

8. Edery, M., C. Jolicoeur, C. Levi-Meyrueis, I. Dusanter-Fourt, B. Pétridou J. M. Boutin, L. Lesueur, P. A. Kelly, and J. Djiane. 1989. Identification and sequence analysis of a second form of prolactin receptor by molecular cloning of complementary DNA from rabbit mammary gland. Proc. Natl. Acad. Sci. USA $86: 2112-2116$

9. Kunkel, T. A. 1985. Rapid and efficient site-specific mutagenesis without phenotypic selection. Proc. Natl. Acad. Sci. USA. 82:488-492.

10. Leung, D. W., S. A. Spencer, G. Cachiancs, R. G. Hammonds, C. Collins, W. J. Henzel, R. Barnard, M. J. Waters, and W. I. Wood. 1987. Growth hormone receptor and serum binding protein: purification, cloning and expression. Nature (Lond.). 330:537-543.

11. Laemmli, U. K. 1970. Cleavage of structural proteins during the assembly of the head bacteriophage T. Nature (Lond.). 227:680-685.

12. Reggio, M., P. Webster, and D. Louvard. 1983. Use of immunocytochemical techniques in studying the biogenesis of cell surface in polarized epithelia. Methods Enzymol. 98:379-396.

13. Louvard, D., M. Regglo, and G. Warren. 1982. Antibodies to the golgi complex and the rough endoplasmic reticulum. J. Cell Biol. 92:92-107.

14. Tar, A., J. F. Hocquette, J. C. Souberbielle, J. P. Clot, R. Brauner, and M. C. Postel-Vinay. 1990. Evaluation of the growth hormone-binding proteins in human plasma using high pressure liquid chromatography gel filtration. J. Clin Endocrinol. \& Metab. 71:1202-1207.
15. Munson, P. J., and O. Rodbard. 1980. Ligand: a versatile computerised approach for characterization of ligand binding systems. Anal. Biochem. 107:220-239.

16. Ymer, S. I., and A. C. Herington. 1985. Evidence for the specific binding of growth hormone to a receptor-like protein in rabbit serum. Mol. Cell. Endocrinol. 41:153-161.

17. Postel-Vinay, M. C., L. Belair, C. Kayser, P. A. Kelly, and J. Djiane. 1991. Identification of prolactin and growth hormone binding proteins in milk. Proc. Natl. Acad. Sci. USA. 88:6687-6690.

18. Kelly, P. A., J. Djiane, M. C. Postel-Vinay, and M. Edery. 1991. The prolactin/growth hormone receptor family. Endocr. Rev. 12:235-251.

19. Daughaday, W. H., and B. Trivedi. 1987. Absence of serum growth hormone binding protein in patients with growth hormone receptor deficiency (Laron dwarfism). Proc. Natl. Acad. Sci. USA. 84:4636-4640.

20. Baumann, G., M. A. Shaw, and R. J. Winter. 1987. Absence of the plasma growth hormone-binding protein in Laron-type dwarfism. J. Clin. Endocrinol \& Metab. 65:814-816.

21. Hocquette, J. F., M. C. Postel-Vinay, J. Djiane, A. Tar, and P. A. Kelly. 1990. Human liver growth hormone receptor and plasma binding protein: characterization and partial purification. Endocrinology. 127:1665-1672.

22. Smith, W. C., and F. Talamantes. 1988. Gestational profile and affinity cross-linking of the mouse serum growth hormone-binding protein. Endocrinology. 123:1489-1494.

23. Lesueur, L., M. Edery, S. Ali, J. Paly, P. A. Kelly, and J. Djiane. 1991. Comparison of long and short form of the prolactin receptor on prolactin-induced milk protein gene transcription. Proc. Natl. Acad. Sci. USA. 88:824-828.

24. Posner, B. I., J. J. M. Bergeron, Z. Josefsberg, M. N. Khan, R. J. Khan, B. A. Patel, R. A. Sikstrom, and A. K. Verma. 1981. Polypeptide hormones: intracellular receptors and internalization. Recent Prog. Horm. Res. 37:539-582.

25. Hocquette, J. F., M. C. Postel-Vinay, C. Kayser, B. de Hemptine, and A. Amar-Costesec. 1989. The human liver growth hormone receptor. Endocrinology. 125:2167-2174

26. Rozakis, M. A., and P. A. Kelly. 1992. Identification of ligand binding determinants of the prolactin receptor. J. Biol. Chem. 267:7428-7433.

27. Bass, S., and J. Wells. 1990. Growth hormone receptor gene in Laron dwarfism. N. Engl. J. Med. 322:854-855.

28. de Vos, A. M., M. Ultsch, and A. A. Kossiakoff. 1992. Human growth hormone and extracellular domain of its receptor: crystal structure of the complex. Science (Wash. DC). 255:257-372. 